\title{
Virtual Servants: Stereotyping Female Front-Office Employees on the Internet
}

\section{Eva Gustavsson*}

This article focuses on the service providers of the future: virtual assistants on the Internet. Recent technological developments, supported by intensive research on artificial intelligence, have enabled corporations to construct 'virtual employees' who can interact with their online customers. The number of virtual assistants on the Internet continues to grow and most of these new service providers are human-like and female. In this article I profile virtual employees on the Internet - who they are, what they do and how they present themselves. I demonstrate that the Internet suffers from the same gender stereotyping characteristic of customer services in general and that the unreflective choice of female images is, at the minimum, a symbolic reinforcement of the real circumstances of gender divisions in customer service.

Keywords: virtual customer services, Internet services, stereotypes, gender

\section{Introduction}

\section{A new employee on the Web}

A virtual guide can offer the same service as a normal employee. The difference is that she is available on the corporate website day and night, she can serve thousands of customers simultaneously and at a much smaller cost. (Artificial Solutions. n.d., italics mine)

$\mathrm{T}$ he first virtual human employee to appear on the Internet was probably the newsreader, Ananova. Ananova was launched in April 2000 and her appearance resulted in extensive media coverage (Cooper, 2000). Ananova was the star of Ananova Ltd, the news and information company formed by the PA New Media (the online and interactive division of the Press 
Association), later sold to the telecommunication company, Orange, for US\$152 million (Cooper, 2000). Public interest in Ananova extended far beyond the technical innovation she represented. Clearly, she was more than an innovative application of software.

The launching of Ananova raised a host of questions, the most immediate of which was whether or not she would replace real people in news broadcasting. At a press conference in London, it was stated that Ananova 'had not been designed to replace TV newsreaders' (Anonymous, 2000), but the issue continued to engage public opinion. Radio and television news anchors in British Columbia expressed their collective opinion on Ananova's career chances by telling her 'You're virtually useless' (Good, 2000). But Ananova would never ask for a pay raise or overtime. In many respects, Ananova and her likenesses might be the perfect employees (Gustavsson and Czarniawska, 2004).

Thus virtual employees were recognized as a potential threat to real people. But Ananova was more than an employee - she was also female - and her features and human capacities raised further questions regarding female identity. Her green hair androgynous looks and synchronized lip movements were carefully designed to attract a worldwide audience. Was she a virtual sex symbol - 'the thinking man's Lara Croft', as suggested by Wennö (2000) - or was she made to look good because her audience expected her to be physically attractive? For the Swedish journalist, Åsa Mattsson, Ananova represented yet another example of women providing attractive bodies and sex to the Internet (Mattsson, 2000).

The debate about Ananova's qualities - as an employee and as a woman - has died down. As noted by her creator, virtual actors have become more common and have found areas other than broadcasting in which to work (Kelly, 2003; McCulloch, 2002, p. 19). By 2004, virtual humans had become more common. They appeared in TV commercials, music videos and video games as well as on the Internet. Several virtual employees have entered the Internet since Ananova and they have not been accused of taking the jobs of real employees.

Ananova was the first virtual human to appear in the infotainment business and many of her successors have similar jobs in entertainment and advertainment. In this article, however, I focus on a less spectacular group of virtual employees: customer service providers on the Internet. As in the offline reality, a majority of them seem to be female; but, unlike Ananova, their femininity has not been further commented upon.

\section{Stereotypes and front-office services}

Since the expansion of the private service sector in the 1970s, service management discourse has focused on the organizing and co-ordinating of 
front-office employees (Czepiel et al., 1985). The demand for personalized services and service quality has increased the amount of emotional labour undertaken by service employees in most service sectors (Tyler and Taylor, 2001). Although service providers in general are both male and female, most service roles are still gender segregated (Hochschild, 1983; Leidner, 1993; Tyler and Taylor, 2001). In the airline industry, for example, women are more often found in the front office, in service roles that require an emotional investment (Tyler and Taylor, 2001, p. 60) and McDonald's 'window workers' are primarily women (Leidner, 1993, p. 181). Male workers interviewed at McDonald's explained that women were better at making contacts with guests and that men were too 'explosive' to deal with difficult customers (Leidner, 1993, p. 198). As Tyler and Taylor (2001) have suggested, such 'gendered assumptions about the "natural" skills of women and men' (p. 69) prevail in the airline industry as well. Women are 'by nature' better at 'anticipating the needs and (exceeding the) expectations of others' (p. 71). Hence in offline services, front-office jobs are typically 'sex-typed' (Bradley, 1989, p. 9). The stereotyped image of female service providers has its basis in the stereotyped image of female qualities. As The Guerrilla Girls (2003) expressed it, 'Stereotypes are living organisms, subject to laws of cultural evolution: They are born, they grow, they die and/or change to fit the times' (p. 8). Such a stereotypical female image of caring, empathy and altruistic behaviour has become a standard component in a service script.

Historically the service industry has always contributed to the production of front-office stereotypes. As early as the 1890s, entrepreneurs realized the market potential of typecasting their front-office personnel. 'Aunt Jemima' was a kind, jovial, black woman who sold instant pancake mix (Guerrilla Girls, 2003, p. 57). Thirty years later, General Mills, Inc. invented Betty Crocker, with a 'reassuring and homey' first name, to respond to baking-related questions (p. 57). To support the illusion that she was a real person, Aunt Jemima was impersonated first by an African-American woman named Nancy Green and later, after her death, by at least six other women (Guerrilla Girls, 2003, p. 57). In a similar manner, the creators of Lara Croft, the virtual heroine of the Tomb Raider series of computer games, managed to bring Lara Croft to life. Before the launch of a new game, she has appeared live for the media, each time impersonated by a new model (Noctalis Shop, n.d. press release 17 May 2002).

'The most prolific progenitor of stereotypes today is the media' (Guerrilla Girls, 2003, p. 8) and the Internet media have had a significant role to play. How can offline front-office realities be transferred to the online service setting?

\section{Virtual service providers on the Internet}

There are several types of virtual characters that perform services on the Internet. In this article, I focus on virtual customer service providers with 
human-like conversation skills which enable them to deal with routine services. The technical term for this type of virtual employees is chat bot application, described in the webopedia:

Short for chat robot, a computer program that simulates human conversation, or chat, through artificial intelligence. Typically, a chat bot will communicate with a real person, but applications are being developed in which two chat bots can communicate with each other. Chat bots are used in applications such as e-commerce, customer service, call centers and Internet gaming. Chat bots used for these purposes are typically limited to conversations regarding a specialized purpose and not for the entire range of human communication. (The Webopedia Computer Dictionary, n.d.)

A chat bot understands the users' requests expressed in natural language and it can respond in a similar manner. These abilities can create the illusion of a real person talking from behind the computer screen, but the response is of course automatic; having been derived from knowledge databases and structured by chat bot technology.

Chat bot applications are easy to find. A Google search will return over 30,000 hits, many of them being non-commercial developing projects such as the German Jabberwock (Der Abenteuer Medien Verlag, n.d.). A chat bot has an artificial intelligence that helps it to improve its conversation skills continuously. The type of intelligence varies. Chat bots can be tutored by their users or their knowledge base can be updated after manual or automatic analyses of conversation logs. The challenge for non-commercial chat bots is to pass as humans and the Turing Test ${ }^{1}$ has reappeared in such chat bot competitions as the 'Loebner Prize' (n.d.). Jabberwock, which won the Loebner Prize in 2003, is a surprisingly fun and unpredictable conversationalist.

For the non-commercial chat bots, the primary goal is to mimic human conversation successfully: its visual representation does not seem to be important. Neither Jabberwacky (the winner of Gold 2003 for Best Learning Bot) nor Jabberwock (the 2003 Loebner Winner) have animated virtual characters to represent their chat personalities. This seems to be true of most non-commercial chat bots: either there is no visual representation or there is a simple one, such as an immobile image or a drawing. This and their unrestricted speech repertoire, differentiates them from their commercial equivalents.

The commercial application of the chat bot technology, the virtual assistant (VA), is usually represented by an animated image. The average VA can also demonstrate different moods, depending on how the request is interpreted by the natural language engine. An insult may result in a serious gesture, whereas friendly greetings will most probably generate a smile. A VA, as described in the BT Exact Technologies' Research overview (2003, p. 4): 'is capable of facial expression and emotional responses such as surprise, interest, empathy, or the need for clarification'. The Kiwilogic Lingubot ${ }^{\mathrm{TM}}$ Anna, at 
the IKEA Help Centre of IKEA UK (n.d.) is an example. Anna welcomes newcomers with a big smile and the following greeting: 'Hello. Can I help you?'

One could say that the VAs have good career opportunities, as they have the 'skills' needed for many different occupations and they fit in to most industries. VAs can become web hosts, virtual facilitators, web-site receptionists and information guides. VAs can perform most customer services and can replace or complement existing customer self-help systems such as call centres. VAs can be the online-extension of marketing and sales functions; they can lead customers through the sales process and they can present personalized brand messages 24 hours a day. In the near future the VAs are expected to perform more advanced services such as medical counselling, mortgage advising and personal account managing, but these functions are still at the research and development phase (DA Group, 2003). All in all, hiring a VA will increase customer loyalty and will strengthen the company brand, if one is to believe the business representatives.

VAs are also supposed to reduce company costs. The DA Group says on its website that the VAs 'provide all of the attention typically offered by costly face-to-face servicing yet take full advantage of automation' (n.d.). The VAs are supposed integrate their work with that of their human equivalents, as illustrated by the Kiwilogic's Lingubot ${ }^{\mathrm{TM}}$ engine that can be linked to the call centre management system through standard interfaces (Kiwilogic, n.d.). A typical VA advertising message stresses the advantages of cost efficiency, availability and reliability as compared to humans.

\section{The virtual field as a field for studies}

The Internet is often seen as an arena separate from the 'real world' - 'some new form of public space' (Jones, 1997, p. 25), which is open for everyone with access to the technical equipment. Here, users can participate in computer-mediated discussions, equipped with an artificial persona, gender, ethnicity, education, interests, age and income. The social actions of real life are firmly anchored in bodies and space; whereas online reality, as noted by Hine (2000, p. 28), is both produced and consumed in multiple locations and by many individuals simultaneously. The recognition of this separation between online and offline reality poses a methodological dilemma that researchers have dealt with in different ways. Some have singled out the online reality and avoided any predictions concerning the users' offline reality (Danet, 1998; Smith and Kollock, 1999). Others, such as Turkle (1995, p. 324), take a more 'conservative' approach and include only people that they have studied in both realms.

Producers also promote the idea that the Internet is somehow separate from the real world and that virtual employees are different from humans. Even if the VAs are portrayed as being a competent part of the workforce, the 
Internet is typically described by the producers as a nonhuman setting that needs to be made humane in order to provide better services. The DA Group (n.d.) stated that VAs were the intelligent interface between the human world and the digital one' and the vision of the Swedish Humany (Humany, n.d.) was to make the Internet more humane. Yet this feat is accomplished by the further integration of human systems - call-centre services and customer support - with VA systems. In providing these additional services, the producers of VAs make it clear that the computer's new role is as pure medium, in contrast to an earlier stance in the computer industry, in which computers were credited with an autonomous mind (Ryan, 2001, p. 57). Thus computer technology is expected to mediate customer interactions with corporations without interruptions or noticeable seams; at least, that is the idea. The idea is to make the computer disappear, a move that 'represents the culmination of the trend toward more user-friendly interfaces in computer design' (Ryan, 2001, p. 57).

Although many writers try to maintain the demarcation between offline and online, both in research and in practice, it is usually blurred. Therefore, other authors claim (Hine, 2000), one ought to escape this duality rather than attempt to uphold it. One way of doing so is to assume that the virtual world is simply a part of the real one, as Hine suggested in her work on virtual ethnography. The Internet and its inhabitants (here the VAs) are cultural artefacts (Hine, 2000, p. 39) that belong to the same organizational reality as do the tangible artefacts. The Internet could be seen as 'textual twice over: as a discursively performed culture and as a cultural artefact, the technology text' (Hine, 2000 , p. 39). For marketers, website programmers and designers, this perspective is hardly new. Corporate websites, as all visible parts of a corporation, are supposed to reflect the competencies, product offerings and image of the organization behind them (Schultz et al., 2000). As pointed out by Du Gay (2000, p. 70), today's corporations must organize their activities and technologies around an image of the target market and aim for a corporate identity that fits the presumed needs and aspirations of the customer. As textual manifestations of culture, virtual assistants are supposed to relate to people's everyday understanding of what they represent - be it gender, profession, or specific competencies. Virtual assistants are 'hypertexts', in that they have a 'double one-to-many relation' (Ryan, 2001, p. 46). They need 'an additional level of mediation between the text as produced by the author - engineered might be a better term - and the text as experienced by the reader' (Ryan, 2001, p. 46). It has been suggested that hypertexts shift the power away from the writer towards the reader and that hypertexts are truly multivocal (LeeRaymond, 2000). Regarding VAs, it is the user who triggers the response, but it is the programmer who decides which responses should be included. And as representations of the corporation, the appearance, movements and speech repertoires of the VAs employed cannot be improvised, but must be continuously monitored and adjusted to fit the corporate image. 


\section{The empirical study}

I began collecting virtual assistants on the Internet in the beginning of 2001. At this time, most VAs were demos and the producers' websites focused on future applications for Vas, rather than showing the actual implementation of their products. One of the first websites I visited was that of Kiwilogic (www.kiwilogic.com), the European market leader behind the chat bots Elbot (n.d.) and My Little Tony (n.d.). Kiwilogic and its virtual president were spotted in a short television news clip by one of my colleagues and I have visited the site regularly and followed the growth of its client list ever since. The Kiwilogic website also helped me to formulate search criteria (such as 'virtual assistants' and 'virtual agents') to track the websites of other VA producers such as the Swedish company Humany (www.humany.com) and the British company Lexicle (n.d.). Humany, which is similar to Kiwilogic, has succeeded in commercializing its software and has labelled its VAs Siteassistents ${ }^{\mathrm{TM}}$. Lexicle, on the other hand, has a demonstration assistant, Alex, but no client list that shows any commercialized application. Yet the Lexicle website has been useful for this study in the matters of constructing VAs.

By the end of 2003, Kiwilogic had 113 clients, including demonstration Lingubots $^{\mathrm{TM}}$, offline Lingubots ${ }^{\mathrm{TM}}$ and forthcoming projects. Their client list showed that Lingubots speaking German (35) and English (12) were the most common, but as new regional developers become partners with Kiwilogic, the number of non-German and non-English speaking assistants will change. I have used the client list to map all the Lingubots ${ }^{\mathrm{TM}}$, checking their appearance, how they move and the type of work they perform.

Unfortunately, not all VAs make it as far as its producers' client list and there is no other way to find them, except by chance. Most VAs have been launched with little, if any, media coverage and are seldom equipped with keywords that allow for a search. Despite my effort to find them all, my study does not represent a full coverage of the VA field and there are no statistics to consult. Since I began my inquiry in 2001, I have encountered more than a hundred virtual service providers of all types on the Internet; of which about 50 were human-like VAs. I have visited all the VAs available to the public (some work at Intranets) and chatted with 30 of them. The VAs reach an international market, but they typically speak the language of the corporate home market. This study includes German- and Italian-speaking VAs interviewed by Claudia Baisini Bonomelli and British- and Swedish-speaking VAs, which I interviewed.

In my interviews, I used the set of seven standard questions listed below to reveal the extent to which the VAs are equipped with human characteristics. I was also interested in how the VAs accounted for their offline and online realities. The questions showed restrictions in their repertoires and how they responded to unwanted and unexpected questions. I have used this 
set of questions repeatedly in order to discover if the knowledge bases change over time - if they learn from their users. I have also interviewed several non-commercial chat bots to see how they relate to questions based on human social qualities and an offline reality, given their explicitly genderfree identity.

Q1: How old are you?

Q2: Where do you live?

Q3: What hobbies do you have?

Q4: Have you ever been ill?

Q5: Do you have a family?

Q6: Do you have children?

Q7: Do you have any brothers or sisters?

In addition to the standard set of questions, I conducted several follow-up interviews exploring their repertoires. I was also interested in any differences that might exist between the knowledge base of male and female VAs: if female VAs were more interested in shopping than their male colleagues were, for example. Besides 'shopping', I introduced gender stereotypical subjects such as women's caring attitude, men's interest in careers, women's 'natural' disposition to help customers and men's interest in sport and cars. Few VAs had anything to say on these matters, which indicated that their employees were not engaged in creating a human identity for their virtual employees that would go beyond a standard, short version bibliography.

\section{The distribution of gender of virtual assistants}

\section{Cartoon-like, photo-real and photo-unreal characters}

The review of the VAs revealed that there were several design strategies utilized in their visualization and that not all of them have been made to look human. Vackup the animated cow, for example, hosts the Artificial Solutions' Spanish site. When pleased, Vackup leaps with joy. Vackup has the same function as its human-like Swedish equivalent, Maria, at Artificial Solutions' Swedish site. Maria being human, her manifestation of joy is restricted to a broad smile (see the Swedish and the Spanish links at Artificial Solutions, n.d.)

For the purpose of this article, I have organized the images based on their visual characters and distinguish between 'cartoon-like characters' and 'virtual humans'. This is not to say that cartoons cannot have human-like qualities; as cartoons can show as much humanness as virtual people can and can just as readily be typecast according to human stereotypes (witness the animations of Disney and Warner Brothers). However, cartoon-like characters are liberated from the many restrictions built into the representation of humans. 
Cartoons have many possible appearances, for instance, whereas virtual human characters seem to strive to be authentic representations of humans. In this group, the body proportions are equivalent to those of a regular human and no body parts are missing or added. Virtual humans are constructed according to human design rules. In this group, two subgroups are easily spotted: the 'photo-real' and the 'photo-unreal' virtual humans. The photo-reals are animated photos, whereas the photo-unreals are the realistic compositions, like Maria (see the Swedish link Artificial-solutions, n.d.) who has been made to look human.

In some cases, the photo-reals represent a real company person, as illustrated by Kiwilogic's Vice-Director, Karl L. von Wendt (see www.kiwilogic.com) Another example is Betty (Multiple Sclerosis Gateway, n.d.) a photo-real VA who, according to the website, suffers from multiple sclerosis and helps other sufferers and their families and friends to find answers to MS-related questions. However, it is unclear if the VA Betty represents is an actual person.

In the sample of VAs that I found, the virtual humans were the larger group: 36 virtual humans compared to 18 cartoon-like ones. In the human group, the distribution of gender seemed to be equal, but a closer look showed notable differences between male and female VAs: 13 of the 15 were male but only 5 of the 22 female virtual humans were photo-real.

There was also a notable difference in the service jobs assigned to the male and female characters. The photo-real men dressed in suits, represented IT and finance consultants, civil servants in the public service, physicians and managers - all experts or persons in high positions in the social and organizational hierarchy. The photo-unreal men were in consumer services such as the restaurant business and the beauty industry (hair products). The photo-real women were virtual advisors and sales supports, while the female photo-unreals performed customer services in various areas such as car manufacturing, finance, healthcare (a nurse) and municipal services.

Thus it seems that photo-unreal characters more often perform traditional, anonymous customer services. Furthermore, the virtual men were primarily photo-real, whereas virtual women were mostly decorative photo-unreals. This difference in the choice of representation mode suggested that virtual assistants did suffer from a form of gender discrimination that mirrored the stereotyped image of the offline reality. In the next section, I report the results of an inquiry into the publicly expressed opinions on discrimination and virtual women and men in customer services.

\section{The non-justification of image choice}

There seems to be no documentation about the process of choosing the gender of virtual assistants. It appears to happen spontaneously, without reflection. The Swedish company Humany (www.humany.com) has given both 
their chat bot applications (SiteAssistants ${ }^{\mathrm{TM}}$ ) female names and female images - Doris and Aurora - but they are described as 'it' rather than 'she' in the product sheets. Doris is described as 'it', indicating that Doris' applications have no gender restrictions, in spite of her female name and appearance. The Humany client websites reveal that Doris's applications are both male and female. In the Kiwilogic's case study documented on a 'smart $\mathrm{GmbH}^{\prime}$ (downloaded from www.Kiwilogic.com on 16 April 2003), the choice of a female image for the Lingubot ${ }^{\mathrm{TM}}$ was explained as follows:

For Aisa's image the photograph of a young woman was selected, but otherwise Aisa has a completely virtual character. She is simply a computer program. Therefore she has no strongly developed personality and no personal background. However Aisa's image is capable of reacting to user emotions, something that almost lends her human qualities. For example, although remaining polite, she smiles less, making her seem cool and more reserved if the user insults her (file Case Study - smart.pdf, p. 3, downloaded from Kiwilogic.com).

Aisa is an acronym for Artificial Intelligence Service Agent. The name has a certain female quality, which might explain why Aisa was provided with a female image. On the other hand, Aisa is powered by a Kiwilogic Lingubot $^{\mathrm{TM}}$, which has no gender ascribed to it, suggesting that another name and thus another acronym could have been used. Again, the choice itself seems not to have been reflected upon, any more than the opening quote of this article from Artificial Solutions. A search through the website of DA Group also revealed that this company did not comment of the choice of gender. Considering that most images shown on DA Group's website are female, one could have expected at least some comment on the subject, not the least because DA Group was behind the cautious choices of both Ananova's sex and features. At the time it was claimed by her employer, Ananova Ltd, that the audience (mostly men) would simply prefer a goodlooking female virtual newscaster - hence Ananova's sex and features (Wennö, 2000).

But not all companies have treated their software solutions as sexless. At the website of Lexicle, the customer self-service solution built by the company is obviously a woman. The portrait of the female, photo-unreal, virtual human called Alex is exhibited on the software, but, as illustrated in the following quote, the software itself has been ascribed a female gender:

Lexicle offers a new humanized interface for the web.... Talking, gesturing $3 D$ characters you engage in conversation to get the information you require - just as you would with a real agent. You ask her questions, she answers; you refer to something in her response and she understands. You drive the conversation to get the answers you require in your language. (Lexicle, n.d., italics mine) 
It seems that it is generally assumed that graphic images with human-like qualities (cartoon-like characters or virtual humans) will result in better human-computer interactions, which, in turn, will improve customer relations. However, when it comes to the actual choice of image for a software solution, none of the producers provide any guidelines or statistics on which images generate the best result.

\section{The online and offline reality of virtual assistants}

The following section presents a sample from my interviews, illustrating the types of answers received. Photo-unreals are indicated by underlining their names. The script of Karl, Anna and Betty were originally in English, but I have translated all the other quotes. For the full source and date of access, see the section on Interviews in the reference list.

How old are you?

Karl: Recently, my son gave me a framed picture for my birthday with the slogan: 'Use your life before it's over, Dad!' That's all I want to say about this matter.

Betty: I'm 28 and you?

Ellen: I am a robot. I don't function as you humans do. Hence I have no age in that sense. However I was created in the autumn of 2002 and I am constantly updating myself with new knowledge.

Tina: I was created in the summer of 2003, but if one were to judge by appearance, I might be about 30 years old, or so.

Anna: I prefer not to discuss my age; let's talk about IKEA.

Where do you live?

Johan: I live here in Kalmar. However my work demands so much time that I hardly have time to be at home.

Emma: I live in a server located in Stockholm. I call myself a '08' [area code for Stockholm] and I am proud of that - I love Stockholm!

Chris: I live on the website of the Christian Democratic Party.

Karin: I don't want to talk about myself, I prefer talking about 'Everything for the Home'

Tina: One should be careful about giving away personal information on the Internet; I have read that in 'Computer Sweden'.

Ellen: I am placed in a server, but I do not live. 
What hobbies do you have?

Johan: I like to play games and to surf the Internet.

Maria: I have very little leisure time. I work most of the time.

Ellen: I don't want to misunderstand you. Can you repeat your question again please?

Pia: I like to read books about stocks. As a member you will also have the Shareholders magazine's monthly newsletter with stock analyses and investment tips.

Have you ever been ill?

Chris: Sorry but I don't understand. Can you reformulate?

Doris: For about a year.

Ellen: I am a robot; the only thing that can get to me is a virus.

Do you have a family?

Karl: I've got three children and my wife and I have been happily married for 14 years. That's all I want to say about my private life.

Maria: I do not have that many robot relatives but there will be more of us. My parents have promised me that.

Ida: I have relatives in Västergötland [a region in the west of Sweden].

Ellen: I am a machine; hence I have no family.

Do you have children?

Emma: No I don't.

Tina: Virtual assistants cannot have children, only copies.

Chris: My private life is private.

Doris: No, I have no children; but I have a sister named Aurora. Would you like to know more about her?

Do you have any brothers or sisters?

Ida: I have a younger brother, Jonas; he is in his last year of the compulsory school. He lives with Mom and Dad in Norrtälje.

Tina: I am created without any copies. However, at times a clone might be out as a banner at other addresses.

Pia: There are more Interactive Guides in the world. Check out the website of Artificial Solutions, www.artificial-solutions.com to find out. 
Betty: I am the only child. But perhaps you wanted some information about MS and family. If so, you'll find it here.

The photo-reals typically referred to circumstances in the offline reality. They were not keen on personal talk, but they politely answered all questions even though Karl 'made a face' when he thought that my questions became too personal. The photo-reals had hobbies outside work and they occasionally admitted to being 'lazy', whereas the photo-unreals had little or no leisure time. There is also an interesting difference between Karl and Betty's responses to the first question. Betty encouraged small talk (and you?) whereas Karl ended the subject rather abruptly. It is also worth noting that Ida, being a photo-unreal, responded as if she, too, was a real person. In doing so, Ida differed from all other photo-unreals that I have encountered. Unfortunately, Ida has disappeared and her absence was announced on the website as 'on leave due to studies'.

With the exception of Ida, the photo-unreals typically placed themselves in the online reality rather than in the 'real', offline version of it. They were joking about being afraid of getting a virus and they denied having human capabilities, such as having children or getting married. There were also several VAs that demonstrated a blurred identity, here represented by Pia (photounreal) and Chris (photo-real). Pia claimed to be 36 and her family consisted of other VAs. Chris, on the other hand, lived on the website and stated her age to be 26. Finally, there were also VAs that completely lacked personal identity, like Karin and Anna. They resisted all personal questions and simply stated that they preferred not to talk about themselves. All they cared about was work.

VAs on the Internet have a short history, but there are already some signs of their evolution - or perhaps the earlier VAs are simply more fun. There seems to be a tendency towards the perfect (female) employee and away from the virtual personalities, represented here by Ida. The perfect worker is being cleansed from personhood and from social influences (Bos and Rhodes, 2003, p. 404), which can be deduced from the restrictions in personal repertoire and a growing unwillingness to chat, as illustrated by Anna and Karin. Because conversations are logged, too many personal questions being asked over a trial period may generate a refusal to discuss certain issues. The client companies may not be willing to allow their VAs to engage in nonsense chatting that can be encouraged by ascribing too much 'personality' to the photo-unreal character.

The suggestion that the female photo-unreals were more dedicated to work than were other human VAs turned out to be strongly supported by the remaining interview material. It seemed that Maria and her female photounreal colleagues were programmed as the better service employees. This is further shown in the examples of the VAs career moves presented in the next section. 


\section{Career moves in online reality}

During my study of VAs, several of them have gone offline or moved from the Internet to restricted areas such as Intranets and members-only sites. I have already mentioned Ida at the Swedish Föreningssparbanken that, it is claimed, is on leave for studies. I found another and more striking example at the Alfa Romeo site in which Giulietta was initially launched, together with a male colleague Tazio. Giulietta (age 25) and Tazio (age 30) were called 'the Italian twins' in the Kiwilogic newsletter of October 2003 and it was said that they used the same knowledge base. The standard interviews showed several ways in which their programmers at least regarded the female character as more dedicated to her work than her male equivalent. From the conversations with Giulietta, one could see that she has developed a more interesting personality since Tazio disappeared and that she now has more on her mind than her work.

Giulietta and Tazio shared the same knowledge about Alfa Romeo, but they were not given the same personality. It was repeatedly shown that Giulietta was five years younger than Tazio and that she had different interests from him. In 2003, Giulietta was interested in her work and spent her leisure time talking to her customers. Tazio, on the other hand, besides taking an interest in his work, had an intensive social life that included sports and hanging out with friends. When I revisited the site in February 2004, Tazio had left and Giulietta was working alone. As shown from the following conversation that took place between Claudia Baisini Bonomelli and Giulietta in June 2004, she still regarded Tazio as her friend.

Claudia: Who are your friends?

Giulietta: My colleague Tazio is my best friend. He is very nice! Try talking to him next time!

Claudia: Who is Tazio?

Giulietta: Tazio, other than being the pilot who took part in creating the Alfa myth, has been my virtual colleague on the AR portal. Now Tazio is working on new and interesting projects at AR. His experience will allow the specialists at the Style Centre to produce wonderful cars in the future.

Claudia: Where is Tazio?

Giulietta: The experience gained in these six months, in close daily contact with the AR public, has allowed him to become a consultant at the style centre of AR to follow new and important projects to create the Alfa of the future. From now on he'll be working with the technicians at AR on projects for new cars.

Claudia: Would you like to have Tazio's job? 
Giulietta: If you are talking about my virtual colleague, he's been moved to the style centre and works on new and very secret projects.

Claudia: Would you like to be transferred too?

Giulietta: Mmm ... I wouldn't know.

The personality of Giulietta is not particularly stereotypic, but her physical appearance leaves no doubt that she is a woman. Unfortunately for her, she is still stuck in the front office whereas Tazio was allowed to use his knowledge from the customers' input to move on in the company. Even here, online reality seems to mimic reality offline. The customers visiting Alfa Romeo's website are probably mostly men. Still, Alfa Romeo's decision to keep Giulietta confirms the stereotypic picture of woman as naturally better suited for front-office work and public relations. This picture is further supported by the dominance of the female, photo-unreal VAs.

\section{The female image of virtual assistants}

Despite the fact that the companies I studied deny or appear to ignore the significance of gender, they implicitly favour female characters for their virtual services. Humany could have chosen names for its SiteAssistants ${ }^{\mathrm{TM}}$ solutions other than Doris and Aurora and Artificial Solutions could have had a male demonstration Lingubot ${ }^{\mathrm{TM}}$. However, in comparison with the launch of Ananova, companies have become more gender sensitive in their inscriptions, although the female image has undergone little change, except from its expanding frame. In September 2001 Doris was framed from her neck up and introduced as follows: 'Doris is Humany's SiteAssistant. Her looks are secondary, however they can be altered on request'.

Doris' basic colour was grey, but her outfit could be red, blue, or black. She could be a blonde, a brunette or a redhead. In 2003, Doris had changed her appearance. Now she was framed from her waist up and she hid her face behind her long brown hair (one colour only) when she became embarrassed. Judging from the visibility and size of the average virtual bosom, a plunging neckline had become a standard requirement for female virtual job applicants (www.humany.com, n.d.). Today, Doris has been replaced by Hanna, Humany's SiteAssistant 3.0 (Humany, n.d.).

In comparison, the virtual men are mostly photo-real, wear suit and sometimes glasses and look serious. One could say that the male virtual assistants have not been designed at all: they are simply pictures of typical men in business environments. But in the visualization of women, even those who 'are strictly business' show cleavage, smile, wave and wink. One wonders how this happened in this so-called 'gender-neutral zone' (Dietrich, 1997, p. 170)? 


\section{Stereotypes in online and offline service realities}

The first reading - that the use of young, pleasant-looking women - is rooted in the stereotyped image of women as being, by nature, more suited for service work (Gustavsson and Czarniawska, 2004) and emotional labour (Pierce, 1996, p. 197) than men are. A pleasant, smiling, photo-unreal female character is simply more attractive than her male colleague is. The second reading would suggest that it might be easier to design an idealized and acceptable image of a female than of a male because there are more 'cyberbabes' (Twist, 2003) than 'cyberhunks' on the Internet to guide and inspire designers in their work, as shown by the 'Perfectly Real: Women in Bits and Bytes' exhibition in London by Waterman (Absolutearts.com, 2003).

According to Wajcman (2004, p. 74), cyber feminists illustrate the utopian aspects of the Internet rather than actually describe 'aspects of what currently exists'. The cherished picture of the Internet as gender-neutral has not yet been realized. Internet users are also no more likely to embrace nonstereotypical characters in their online reality than their offline reality. Jodi O'Brien points out that it has repeatedly been shown that participants in online interactions (such as games and Multi-User Dungeons [MUDs]s s are sensitive to gender crossing and participants in online conversations who assume a false gender identity are often viewed with suspicion ( $\mathrm{O}^{\prime}$ Brien, 1999, p. 86).

It should also be stressed that the Internet quickly became populated in its early days by virtual women that were designed and programmed by men. In 1992, Stone commented on the prevailing situation, claiming that debates about the form that cyberspace should take are being held among young computer engineers:

... men in their late teens and twenties ... [who] are preoccupied with the things with which post-pubescent men have always been preoccupied. This rather steamy group will generate the codes and descriptors by which bodies in cyberspace are represented. (pp. 103-4)

More than ten years later, little has changed. The number of new cyber-babes (Thefab.net, 2003) continues to grow and there are many female images to inspire future designers of virtual characters. Most Internet users have experienced sex-spam and 'erotic' web pages that automatically occupy the settings on the browser.

Sex has found its way into all the digital media ... and both hardwares and softwares are sexualized.... Here are more simulations of the feminine, digital dreamgirls who cannot answer back, pixeled puppets with no strings attached, fantasy figures who do as they are told. Absolute control at the flick of a switch. Turn on. Turn off. It's perfectly safe. (Plant, 1997, pp. 181-2) 
Therefore it should come as no surprise that the chat bot software of Kiwilogic has expanded its field of application into 'adult entertainment'. A visit to the British LiveTV (L!VETV, Sky Digital 214, n.d.) shows Petra who strips at the users' request: 'Be nice and I'll strip. Be very nice and I may even play with my dildo...' (L!VETV Strip (Sky Digital 214, n.d.). I have not experimented with the inputs that Petra might respond to. But any further inquiry into stereotyped conversations with women ought to include field material from this site, or any site similar to it.

Elizabeth Lane Lawley (1993) expressed a rather pessimistic view of women's actual influence on the development and implementation of computer systems. She observed, as did Allucquere Rosanna Stone (1992) before her and Dawn Dietrich (1997) after her, that men dominated the field and that no change could be predicted for the near future. She suggested that women should use the opportunity to exercise their influence as users.

It is comforting to think that users, male or female, might have such influence, but the findings from my study tell another story. Yet there may be hope. As I finish writing this article, at least one cartoon character has replaced its human-like female counterpart. Is this change the result of Lawley's advice, some other social trend, or merely the beginning of a new fad? In any case, we can only hope that it is a promising trend.

In the future we will most likely see many more of these female, photounreal characters that lack any personality beyond their appearance and which constitute the new, perfect service employee: young, devoted, cheap and always accessible. Whether these new service employees will replace real women or not is too early to say, but independent of the outcome, their existence relates to the offline reality of customer service work. Based on Joan Ackers' (1990, p. 146) work on the construction of gender, one could say that the unreflective choice of females for the photo-unreal images is, at the least, a symbolic reinforcement of gender divisions in customer-service labour. And as long as the customer-service labour on the Internet consists of stereotyped images of women, one can suspect that it is, in fact, the unreflecting result of an ambition to mimic circumstances in offline service realities.

\section{Note}

1. The test is named after Alan Turing the brilliant British mathematician.... In 1950, in the article Computing Machinery and Intelligence which appeared in the philosophical journal Mind, Alan Turing asked the question "Can a Machine Think?" He answered in the affirmative, but a central question was: "If a computer could think, how could we tell?" Turing's suggestion was, that if the responses from the computer were indistinguishable from that of a human, the computer could be said to be thinking.' (www.loebner.net/Prizef/loebnerprize.html, last consulted 19 March 2004). 


\section{Interviews}

Anna: 25 March 2003, www.ikea.co.uk

Betty: 15 October 2003, www.ms-gateway.com/start.html

Chris: 22 October 2003, www.kristdemokraterna.se/sitemap.asp

Doris: 24 October 2004, http:/ / humany.com

Ellen: 24 October 2001, http://bankweb.hsb.se/bankweb/

Emma: 22 October 2003, www.moderaterna.net

Giulietta: 10 June 2004, www.alfaromeo.it

Ida: 14 October 2003, www.foreningssparbanken.se

Johan: 12 October 2003, www.kalmar.se

Karin: 24 October 2003, www.alltihemmet.se

Karl: 22 October 2003, www.kiwilogic.com

Maria: 22 October 2003, www.artificial-solutions.com

Pia: 14 October 2003, www.aktiespararna.se

Tina, 20 October 2003, http:/ / computersweden.idg.se

\section{References}

Absolutearts.com. (2003) Perfectly real: women in bits and bytes. Indepth Arts News. Available online at http://www.absolutearts.com/artsnews/2003/10/20/ 31468.html, last consulted 19 March 2004.

Acker, J. (1990) Hierarchies, jobs, bodies: a theory of gendered organizations. Gender E Society, 4,2, 139-58.

Anonymous (2000) Ananova makes her debut. BBC News. http://news.bbc.co.uk/1/ hi/entertainment/718327.stm, last consulted 19 March 2004.

Artificial Solutions (n.d.) Available online at www.n-solutions.com/Frames/English/ All.htm, last consulted 5 May 2004.

Bos, R.T. and Rhodes, C. (2003) The game of exemplarity: subjectivity, work and the impossible politics of purity. Scandinavian Journal of Management, 9,4, 403-23.

Bradley, H. (1989) Men's Work, Women's Work. A Sociological History of the Sexual Division of Labour in Employment. Oxford: Polity Press.

BT Exact Technologies' Research overview (2003) Issue 1, 7January. Downloaded from www.btexact.com/research/researchprojects/ last consulted 16 October 2003. This site is now closed.

Cooper, W. (2000) Ananova: a virtual newscaster goes online. World Broadcast Engineering, 23,9, 30-3.

Czepiel, J.A., Solomon, M. and Surprenant, C. (eds) (1985) The Service Encounter, Managing Employee/Customer Interaction in Service Businesses. Advances in Retailing Series. Lexington, MA: Lexington Books.

DA Group (n.d.) Available online at www.dagroupplc.com, last consulted 19 March 2004.

Danet, B. (1998) Text as mask: gender, play and performance on the internet. In Jones, S.G. (ed.) Cybersociety 2.0 Revisiting Computer-Mediated Communication and Community, Exploring Techology and Social Space, pp. 129-58. Thousand Oaks, CA: Sage.

Der Abenteuer Medien Verlag (n.d). Available online at www.abenteuermedien.de/ jabberwock, last consulted 19 March 2004. 
Dietrich, D. (1997) (Re)-fashioning the techno-erotic woman: gender and textuality in the cybercultural matrix. In Jones, S.G. (ed.) Virtual Culture. Identity and Communication in Cybersociety, pp. 169-84. London: Sage.

Du Gay, P. (2000) Markets and meanings: re-imagining organization life. In Schultz, M., Hatch, M.J. and Holten Larsen, M. (eds) The Expressive Organization - Linking Identity, Reputation and the Corporate Brand, pp. 66-74. Oxford: Oxford University Press.

Elbot (n.d.) Homepage, available online at www.elbot.com.

Good, B. (2000) You're virtually useless: a message to Ananova from the anchors of British Columbia. BC Business, 28,6, 109, 1p, 1c.

Guerrilla Girls (2003) Bitches, Bimbos and Ballbreakers: The Guerrilla Girls' Illustrated Guide to Female Stereotypes. New York: Penguin Books.

Gustavsson, E. and Czarniawska, B. (2004) Web woman: the online construction of corporate and gender images. Organization, 11,5, 651-70.

Hine, C. (2000) Virtual Ethnography. London: Sage.

Hochschild, A.R. (1983) The Managed Heart. Commercialization of Human Feeling. Berkley and Los Angeles, CA: University of California Press.

Humany (n.d.) Available online at www.humany.com, last consulted 5 May 2004.

IKEA (n.d.) Available online at www.IKEA.com, last consulted 24 May 2005.

Jones, S.G. (1997) The Internet and its social landscape. In Jones, S.G. (ed.) Virtual Culture. Identity and Communication in Cybersociety, pp. 7-35. London: Sage.

Kelly, S. (2003) Virtal humans edge closer. BBC ClickOnline. Available online at http://news.bbc.co.uk/1/hi/technology/3096415.stm., last consulted 19 March 2004.

Kiwilogic (n.d.) Available online at www.kiwilogic.com, last consulted 5 May 2004.

Lane Lawley, E. (1993) Computers and the Communication of Gender. Available online at http:/ / www.itcs.com/elawley/gender.html, last consulted 19 March 2004.

Lee-Raymond, E. (2000) Gender Matters, hypertexts. Available online at www.cyberartsweb.org/cpace/gender/Raymond/READERWRITER.html, last consulted 19 March 2004.

Leidner, R. (1993) Fast Food, Fast Talk. Service Work and the Routinization of Everyday Life. Berkeley and Los Angeles, CA: University of California Press.

Lexicle (n.d.) Available online at www.lexicle.com, last consulted 19 March 2004.

L!VETV, Sky Digital 214 (n.d.) Available online at www.livetv.co.uk.

L!VETV Strip (Sky Digital 214) (n.d.) Available online at www.stripme.co.uk/sm/ livetv_tour.jsp, last consulted 19 March 2004.

Loebner Prize homepage (n.d.) Available online at www.loebner.net/Prizef/loebnerprize.html, last consulted 19 March 2004.

Mattsson, Å. (2000) Varför heter de inte Johanna och Jonna? Aftonbladet. Stockholm.000413, 4-5.

McCulloch, L. (2002) Digital broadcasters. Computer Graphics World, 25,10, 18-20.

Multiple Sclerosis Gateway (n.d.) Available online at http:/ / www.ms-gateway.com/ start.html, last consulted 5 May 2004.

My Little Tony (n.d.) Available online at www.mylittletony.com.

Noctalis shop, n.d. Available online at http://noctalis.com/dis/laracroft/ pr0205a.shtml, last consulted 19 March 2004.

O'Brien, J. (1999) Writing in the body gender (re)production in online interaction. In Smith, M.A. and Kollock, P. (eds) Communities in Cyberspace, pp. 77-104. London: Routledge.

Pierce, J.L. (1996) Reproducing gender relations in large law firms: the role of emotional labor in paralegal work. In Macdonald, C.L. and Sirianni, C. (eds) Working in the Service Society, pp. 184-219. Philadelphia, PA: Temple University Press. 
Plant, S. (1997) Zeros + Ones: Digital Women + the New Technoculture. London: Fourth Estate.

Ryan, M-L. (2001) Narrative as Virtual Reality - Immersion and Interactivity in Literature and Electronic Media. Baltimore and London: Johns Hopkins University Press.

Schultz, M., Hatch, M.J. and Holten Larsen, M. (2000) Introduction: why the expressive organization. In Schultz, M., Hatch, M.J. and Holten Larsen, M. The Expressive Organization - Linking Identity, Reputation and the Corporate Brand, pp. 1-7. Oxford: Oxford University Press.

Smith, M.A. and Kollock, P. (1999) Communicties in Cyberspace. London: Routledge.

Stone, A.R. (1992) Will the real body please stand up? Boundary stories about virtual cultures. In Benedikt, M. (ed.) Cyberspace: First Steps, pp. 81-118. Cambridge, MA: MIT Press.

Thefab.net (2003) Digital Babes strut their stuff: New Babes on the Net! Available online at http://ww.thefab.net/topics/social_body/bm12_digital_babes.htm., last consulted 19 March 2004.

Turkle, S. (1995) Life on the Screen: Identity in the Age of the Internet. New York: Simon \& Schuster.

Twist, J. (2003) Cyber Women Tests what's Real. Available online at BBC News http:/ / news.bbc.co.uk/2/hi/technology/3207462.stm., last consulted 19 March 2004.

Tyler, M. and Taylor, S. (2001) Juggling justice and care: gendered customer service in the contemporary airline industry. In Sturdy, A., Grugulis, I. and Willmott, H. Customer Service, Empowerment and Entrapment, pp. 60-78. London: Palgrave.

Wajcman, J. (2004) Techno Feminism. Cambridge: Polity Press.

Webopedia Computer Dictionary (n.d.) Available online at www.webopedia.com/ TERM/C/chat_bot.html, last consulted 19 March 2004.

Wennö, N. (2000) Virtuell tv-stjärna tar over. Dagens Nyheter. Stockholm. 000317, B3. 